\title{
Teoria inteligentnego projektu a nadnaturalizm - 0 tezie, że projektantem może być Bóg lub istoty pozaziemskie
}

\begin{abstract}
Streszczenie: Kiedy rzecznicy teorii inteligentnego projektu (ID) zaprzeczają, że ich teoria ma charakter religijny, opowiadają się za teorią minimalistyczną (teorią mini-ID), według której odkryte w naturze nieredukowalnie złożone adaptacje są dziełem jednego lub większej liczby inteligentnych projektantów. Nie uznają jej za religijną, ponieważ nie określa ona tożsamości projektanta - dzieła stworzenia mógł dokonać nadprzyrodzony Bóg lub grupa istot pozaziemskich. W niniejszym artykule próbuję wykazać, że teza ta bagatelizuje konsekwencje płynące $z$ teorii mini-ID. Teoria mini-ID uzupełniona o kolejne cztery założenia, których wiarygodność została ustalona niezależnie, pociąga istnienie nadprzyrodzonego inteligentnego projektanta. W dalszej części artykułu dowodzę, że takie teorie naukowe, jak darwinowska teoria ewolucji, nie wypowiadają się na temat istnienia nadprzyrodzonych projektantów.
\end{abstract}

\footnotetext{
*Elliott Sober, „Intelligent Design Theory and the Supernatural: The «God or Extra-Terrestrials» Reply", Faith and Philosophy 2007, vol. 24, s. 72-82, http://philosophy.wisc.edu/ sober/ID\%20and\%20the\%20Supernatural\%20final\%20F\&P\%20single.pdf (18.11.2008). Za zgodą Autora z języka angielskiego przełożył Sławomir PIEснасzeк. Recenzent: Józef Zon, Katedra Biologii Teoretycznej Katolickiego Uniwersytetu Lubelskiego.
} 


\section{Jakie jest prawdziwe oblicze teorii ID?}

Czym jest teoria inteligentnego projektu (ID)? Odpowiedź na to pytanie jest o tyle skomplikowana, że podczas gdy jedna wersja tej teorii jest minimalistyczna, inne są o wiele bardziej pojemne. Wersja minimalistyczna, którą będę nazywał teorią mini-ID, mówi jedynie, że posiadane przez organizmy nieredukowalnie złożone adaptacje są dziełem jednego lub większej liczby inteligentnych projektantów. ${ }^{1}$ Tożsamość tych projektantów jest nieokreślona; może oko kręgowców zostało stworzone przez grupę istot pozaziemskich, a może przez Boga, który żyje poza czasem i przestrzenią. Teoria mini-ID nie przeczy, że ludzie posiadają wspólnych z innymi gatunkami przodków, nie upiera się również przy młodym wieku Ziemi, ani nie wyjaśnia pochodzenia Wszechświata. Tym, co różni ją od pewnych wcześniejszych wersji kreacjonizmu, jest skromność. ${ }^{2}$

Obrońcy teorii mini-ID mają o wiele więcej do powiedzenia na temat inteligentnego projektu i właśnie wtedy ma się do czynienia z bardziej pojemnymi wersjami teorii ID. Na przykład Phillip Johnson, ${ }^{3}$ je-

\footnotetext{
${ }^{1}$ M. Behe, Czarna skrzynka Darwina. Biochemiczne wyzwanie dla ewolucjonizmu, przeł. Dariusz Sagan, Biblioteka Filozoficznych Aspektów Genezy, t. 4, Wydawnictwo MEGAS, Warszawa 2008; M. BeHE, „Design for Living”, New York Times, 7 February 2005, s. A27; W. DemBski, „What Every Theologian Should Know about Creation, Evolution, and Design", Center for Interdisciplinary Studies Transactions 1995, vol. 3(2), s. 1-8, www.arn.org/docs/demski/wd.theologn.htm; W. Dembsкi, „Introduction”, w: W. DemBSKI (ed.), Mere Creation: Science, Faith, and Intelligent Design, InterVarsity, Downers Grove, IL. 1998, s. 15 [13-32].

${ }^{2}$ Chociaż niektórzy teoretycy ID przeczą, jakoby teoria ID była odmianą kreacjonizmu, gdyż teoria mini-ID nie wspomina o Bogu, nie wszyscy teoretycy ID się z tym zgadzają; na przykład William Dembski mówi, że „szeroko rozumiany kreacjonizm” jest „wiarą w to, że Bóg lub pewien inteligentny czynnik stworzył życie celowo [kursywa moja]” (DemBski, „What Every Theologian Should Know...").

${ }^{3}$ P. Johnson, ,Starting a Conversation about Evolution: A Review of The Battle of the Beginnings: Why Neither Side is Winning the Creation-Evolution Debate by Del Ratzsch", Access Research Network 1996, www.arn.org/docs/johnson/ratzsch.htm (18.11.2008).
} 
den z głównych architektów teorii ID, popiera realizm teistyczny ,głosząc, że Bóg istnieje obiektywnie jako Stwórca i że rzeczywistość Boga została wyraźnie zapisana w świadectwach dostępnych nauce, szczególnie biologii”; jak mówi, jest to „kluczowa koncepcja naszego ruchu”. W powszechnie używanym podręczniku ID - Of Pandas and People [O pandach i ludziach], Percival Davis i Dean Kenyon ${ }^{4}$ często przeciwstawiają przyczyny „naturalne” przyczynom ,inteligentnym”. Oznacza to, że wspominani przez nich inteligentni projektanci mają charakter nadnaturalny. Z kolei Dembski ${ }^{5}$ odrzuca teistyczny ewolucjonizm, który głosi, iż Bóg posłużył się procesami ewolucyjnymi w celu stworzenia organizmów i ich cech adaptacyjnych. Problemem dla Dembskiego nie jest boski projekt, lecz teoria ewolucji. ${ }^{6}$

Skoro teoretycy ID tak często i na różne sposoby wykraczają poza teorię mini-ID, pojawia się pytanie, dlaczego została ona sformułowana jako odrębne stanowisko? Jedną z przyczyn tego stanu rzeczy sugeruje komentarz Johnsona, iż ,ludzie reprezentujący różne stanowiska teologiczne powinni rozpoznać podobnych sobie, zawrzeć sojusze i odłożyć na później kwestie będące zarzewiem podziału [...] Dopiero po tym, jak rozstrzygniemy kwestię Stwórcy, będziemy mieli świetną okazję, aby spierać się o wiek Ziemi". ${ }^{7}$ Skromna teoria posiada tę zaletę, iż potrafi jednoczyć walczące ze sobą frakcje przeciwko wspólnemu wrogowi. Ponadto, nie używająca słowa „Bóg” teoria mini-ID może mieć większe szanse, niż jej kreacjonistyczne poprzedniczki,

${ }^{4}$ P. Davis and D. Kenyon, Of Pandas and People: The Central Question of Biological Origins, 2nd ed., Haughton Publishing Co., Dallas, Texas 1993, s. 7, 26, 100.

${ }^{5}$ Dembski, „Introduction...”, s. 20.

${ }^{6}$ Teoretycy ID często odbiegają od minimalizmu teorii mini-ID pod innym względem. Davis i Kenyon (Of Pandas and People..., s. 39) przeczą, jakoby organizmy, będące przedstawicielami różnych „kategorii wyższego rzędu”, miały wspólnych przodków, zaś Dembski („What Every Theologian Should Know...”) twierdzi, że ludzie zostali stworzeni celowo. Tylko Behe wydaje się być jedynym czołowym teoretykiem ID, który opowiada się (aczkolwiek ,tymczasowo”) za ideą wspólnego przodka (W. DemBski, Intelligent Design: The Bridge between Science and Theology, InterVarsity, Downers Grove, IL. 1999, s. 250).

${ }^{7}$ Cyt. za: K. WALKER, „Young-Earth Theory Gains Advocates”, Christianity Today 1998, vol. 45 , s. 24. 
aby przejść sprawdzian na zgodność z Konstytucją, która zakazuje propagowania religii $\mathrm{w}$ szkołach publicznych.

Inną przyczynę tego, że teoria mini-ID została sformułowana jako osobne stanowisko, ukazuje opracowana przez Discovery Institute „Strategia klina”. ${ }^{8}$ Mający swą siedzibę w Seattle, Discovery Institute jest dobrze dobranym zespołem doradców ID, zaś "Strategia klina” stanowi manifest polityczny tej organizacji. Ów dokument ma charakter notatki do użytku wewnętrznego, której treść wyciekła do Internetu w 1999 roku; w niej właśnie Discovery Institute stawia sobie za cel „zastąpienie wyjaśnień materialistycznych ujęciem teistycznym, w myśl którego przyroda $\mathrm{i}$ istoty ludzkie zostały stworzone przez Boga". Phillipa Johnsona krytyka darwinizmu ${ }^{9}$ oraz Michaela Behe'ego zastosowanie teorii mini-ID do pewnych złożonych adaptacji biochemicznych ${ }^{10}$ są tam przedstawione jako „ostrze klina”, której celem jest rozdarcie „olbrzymiego drzewa” „materialistycznej nauki”. Zgodnie ze „Strategią klina” „teoria projektu obiecuje ukrócić duszącą dominację światopoglądu materialistycznego i zastąpić go nauką zgodną z przekonaniami chrześcijańskimi oraz teistycznymi”".

Czym zatem jest teoria ID? Czy jest nią właśnie teoria mini-ID, czy też w grę wchodzi bardziej treściwa hipoteza mówiąca, iż przystosowania organizmów i sam Wszechświat zostały stworzone przez chrześcijańskiego Boga, a może jest to jakieś stanowisko pośrednie? Druga $\mathrm{z}$ tych propozycji ma oczywiście charakter religijny, natomiast pierwsza, tylko z pozoru, nie ma takiego charakteru. Nie jest celem tego artykułu dalsze omawianie motywów stojących za sformułowaniem teorii mini-ID, ani przedstawienie dowodu, że jedna $\mathrm{z}$ tych wersji teorii ID jest „prawdziwą” teorią inteligentnego projektu. Chciałbym raczej przeanalizować implikacje wynikające $\mathrm{z}$ tego, co teoria mini-ID faktycznie głosi. Uzupełniona o cztery niezależnie potwier-

\footnotetext{
${ }^{8}$ Dostępna pod adresem: http://www.antievolution.org/features/wedge.html(18.11.2008).

${ }^{9}$ P. Johnson, Sąd nad Darwinem, przeł. Robert Piotrowski, Oficyna Wydawnicza „Vocatio", Warszawa 1997.

${ }^{10}$ BeHe, Czarna skrzynka Darwina....
} 
dzone założenia, skłania ona do przyjęcia tezy o istnieniu nadprzyrodzonego inteligentnego projektanta.

\section{Zastosowanie argumentu z pierwszej przyczyny do teorii mini-ID}

Rozważmy następujący argument, zainspirowany poglądami Tomasza z Akwinu. Nie jest to argument, który popieram osobiście, lecz na który teoretycy ID powinni udzielić odpowiedzi.

1. Jeżeli jakiś system występujący w świecie przyrody jest nieredukowalnie złożony, przyczyną jego istnienia musiał być inteligentny projektant.

2. Niektóre umysły występujące w świecie przyrody są nieredukowalnie złożone.

3. Zatem przyczyną istnienia niektórych umysłów musiał być inteligentny projektant.

4. Każdy umysł, będący częścią przyrody, który projektuje i tworzy nieredukowalnie złożone układy, sam jest nieredukowalnie złożony.

5. Jeżeli Wszechświat nie istnieje nieskończenie długo i jeśli przyczyna poprzedza skutek, to przynajmniej jeden z umysłów występujących w świecie przyrody nie został stworzony przez jakikolwiek inny umysł tam istniejący.

6. Wszechświat nie istnieje nieskończenie długo.

7. W świecie przyrody przyczyna poprzedza własny skutek.

8. Zatem istnieje nadprzyrodzony inteligentny projektant.

W argumencie tym przesłanki nie mające faktycznie żadnego związku z religią wiodą do wniosku o zgoła religijnym charakterze. 


\section{Komentarz do argumentu}

Przesłanka pierwsza jest kluczowym twierdzeniem teorii mini-ID. Posługuję się tutaj wyrażeniem Behe'ego ${ }^{11}$ - ,nieredukowalna złożoność”, które on sam definiuje jako ,[...] pojedynczy system, złożony z poszczególnych dobrze dopasowanych, oddziałujących ze sobą części, które wspólnie pełnią podstawową funkcję układu, a usunięcie jakiejkolwiek z tych części powoduje, że system przestaje sprawnie funkcjonować". ${ }^{12}$ Taką samą koncepcję rozwijał Paley; ${ }^{13}$ zegarek oraz oko pełnią pewne funkcje, takie jak mierzenie czasu czy postrzeganie, jednakże przestaną je spełniać, jeśli jedna ze współdziałających ze sobą części zostanie usunięta.

Przesłanka druga może być prawdziwa nawet wtedy, kiedy nie jesteśmy pewni, jakie systemy naturalne są wyposażone w umysły. Przyjmuję, że człowiek ma umysł. Powyższy schemat sugeruje, że ludzki umysł jest nieredukowalnie złożony. ${ }^{14}$ Najważniejszą funkcją tego systemu jest umożliwienie jednostkom skutecznego prosperowania w ich własnym środowisku. ${ }^{15}$ Nasze obecne przekonania i pragnienia pozostają pod wpływem wspomnień oraz stanów postrzeżeniowych, w jakich aktualnie się znajdujemy. Poprzez przejście do ja-

\footnotetext{
${ }^{11}$ Beнte, Czarna skrzynka Darwina..., s. 43.

${ }^{12}$ Odwołuję się do tego wyrażenia, mimo że wskazuje ono (moim zdaniem zwodniczo) na redukcjonizm.

${ }^{13}$ W. PAley, Natural Theology, or, Evidences of the Existence and Attributes of the Deity, Collected from the Appearances of Nature, Rivington, London 1800.

${ }^{14} \mathrm{~W}$ odniesieniu do tego argumentu wystarczy, by tylko niektóre, nie zaś wszystkie, umysły ludzkie były nieredukowalnie złożone.

${ }^{15}$ Ktoś może zasugerować, że funkcja umysłu powinna zostać opisana bardziej szczegółowo. Dla Behe'ego będzie problemem, jeśli szczegółowość opisu funkcji wpłynie na ocenę, czy układ jest nieredukowalnie złożony. Biorąc jednak pod uwagę nasz schemat, przypisanie bardziej konkretnej funkcji (na przykład: „umożliwienie jednostkom skutecznego prosperowania w ich własnym środowisku dzięki konstruowaniu mentalnych reprezentacji i manipulowaniu nimi”) zdaje się nie mieć takiego wpływu.
} 
kiejś procedury decyzyjnej owe przekonania i pragnienia stają się źródłem intencji (planu działania). Intencje skłaniają nas do podjęcia działania. Jeśli jakakolwiek z przedstawionych powyżej części zostanie usunięta, umysł nie będzie w stanie spełniać swojej funkcji. Przesłanka druga nie wymaga, by ów podział ludzkiego umysłu na części był zupełny. Poza tym, może być on charakterystyczny nie tylko dla człowieka; moim zdaniem za jego pomocą możemy również opisać umysły istot inteligentnych, które projektują i wytwarzają nieredukowalnie złożone systemy, niezależnie od tego, czy są ludźmi. Tym samym, znajdujemy uzasadnienie dla przesłanki czwartej.

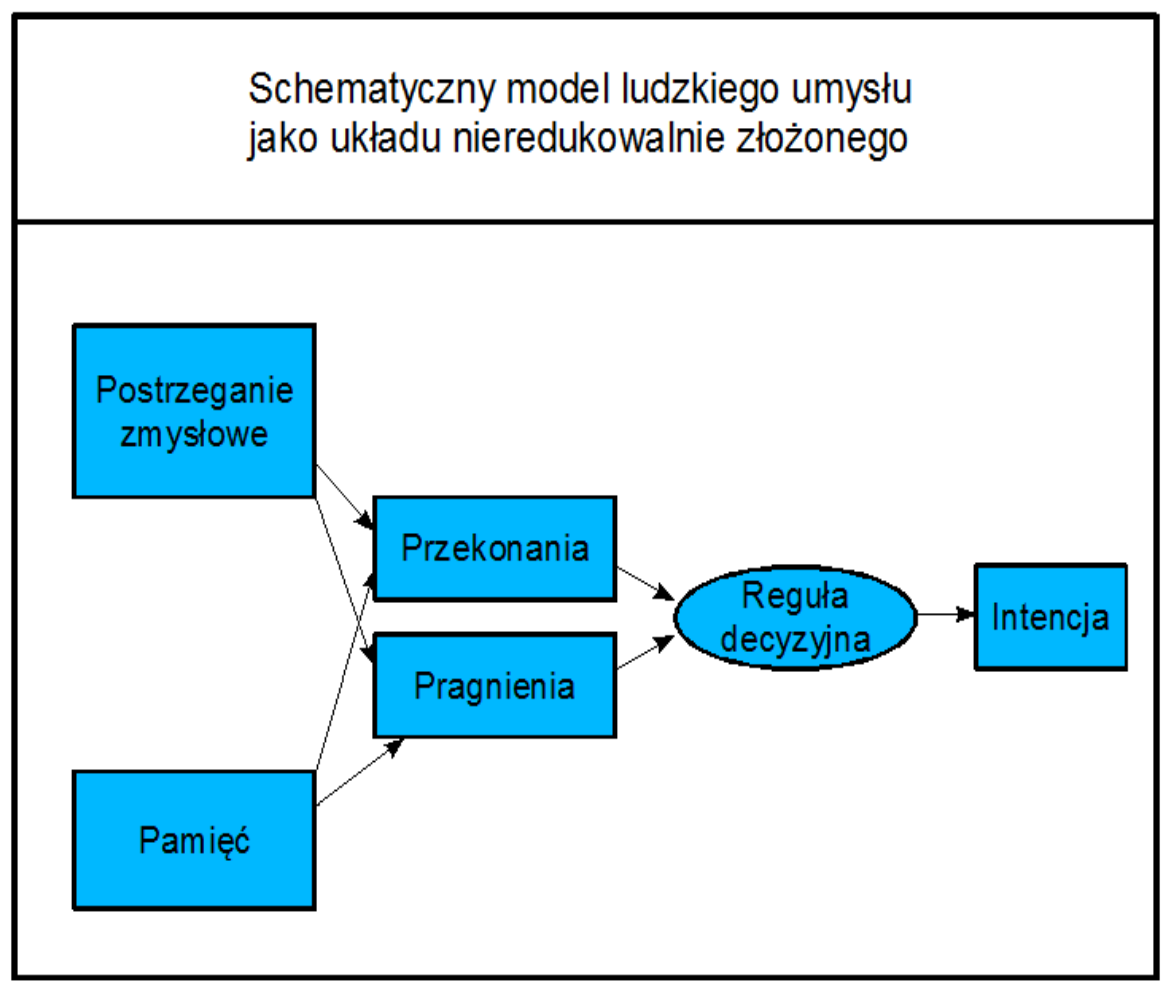

Można spotkać się z zarzutem wysuwanym pod adresem przesłanek drugiej i czwartej, który bierze się z pewnej dwuznaczności, zwią- 
zanej z zaproponowanym przez Behe'ego pojęciem nieredukowalnej złożoności. Istnieje wiele sposobów na to, by podzielić system na części. Czy będzie on traktowany jako nieredukowalnie złożony, zależy od przyjętego kryterium podziału. Rozważmy przypadek oka. Jeżeli za części oka weźmiemy rogówkę, siatkówkę itd., to cały system zostanie uznany za nieredukowalnie złożony. Jednakże jeśli poszczególne części oka będziemy rozumieć jako zbiory atomów, wniosek będzie taki, że oko nie jest systemem nieredukowalnie złożonym; usuńmy pojedynczy atom, a oko nadal będzie widzieć. Sugeruje to, iż według Behe'ego dany układ należy uznać za nieredukowalnie złożony tylko wtedy, gdy jakiś konkretny, nie zaś każdy podział na części spełnia jego definicję. $Z$ tą interpretacją wiąże się jednak pewien problem. Otóż w przypadku, gdy zastosujemy podział na dostatecznie duże części, wiele wysoce redundantnych systemów trzeba będzie uznać za nieredukowalnie złożone. Rozważmy przypadek butelki wina. Zakładam, iż funkcją butelki jest magazynowanie jakiegoś płynu. Można dokonać podziału na bardzo małe części, z którego wynika, iż butelka nie jest nieredukowalnie złożona - „odkrojenie” niewielkiego fragmentu powierzchni butelki nie wpłynie niekorzystnie na jej zdolność magazynowania płynu. Jednakże istnieje inny podział, który prowadzi do przeciwnego wniosku. Załóżmy, iż dzielimy butelkę na pewną liczbę identycznych co do kształtu kawałków; z chwilą, gdy usuniemy jakąkolwiek z tych części, butelka przestanie spełniać funkcję pojemnika na płyn. Możliwej odpowiedzi na tę trudność dostarcza twierdzenie, w myśl którego istnieje jeden poprawny podział systemu na części; pojawia się jednak pytanie, w jaki sposób ten jedyny poprawny podział zdefiniować i jak go uzasadnić? Wspomniałem o tym problemie, gdyż pokazuje on, jak błędna jest argumentacja przeciwko przesłance drugiej, mówiąca, iż podział ludzkiego umysłu na małe części prowadzi do wniosku, że umysł nie jest nieredukowalnie złożony. Nie jestem pewien, jak należy rozumieć koncepcję Behe'ego, ale wydaje się, że ci, którzy utrzymują, jakoby wić bakteryjna oraz biochemiczny proces krzepnięcia krwi były nieredukowalnie złożone, powinni utrzymywać, że ludzki umysł również jest nieredukowalnie złożony. 
Również przesłanka szósta nie jest częścią teorii mini-ID; jest ona raczej częścią najlepszej, jaką obecnie dysponujemy, naukowej wiedzy o świecie. Fizyka mówi nam, że Wszechświat jest skończony w czasie. ${ }^{16}$ To samo dotyczy przesłanki siódmej; nie jest ona częścią teorii mini-ID, bo i z tym trzeba się zgodzić, że w naturze przyczyny poprzedzają ich skutki. ${ }^{17}$

Podsumujmy to rozumowanie: jeśli ludzkie umysły, występujące obecnie $\mathrm{w}$ naturze, są nieredukowalnie złożone, to przyczyną istnienia każdego z nich był jeden lub więcej wcześniej istniejących inteligentnych projektantów. Zastanówmy się nad jednym spośród tych projektantów: albo jest on częścią natury, albo istotą nadprzyrodzoną. Jeśli to drugie, to wszystko jasne - twierdzenie ósme wynika z przesłanek. Rozważmy więc pierwszą możliwość. Inteligentny projektant, który zaprojektował i stworzył nieredukowalnie złożony umysł, również musi posiadać taki umysł. Jeśli jakiś naturalny umysł (np. człowiek) potrzebuje pewnej skończonej ilości czasu $\varepsilon$ do zaprojektowania i stworzenia innego nieredukowalnie złożonego inteligentnego projektanta, to łańcuch przyczynowy, łączący późniejszego naturalnego inteligentnego projektanta z poprzedzającym go (również naturalnym) inteligentnym projektantem, będzie miał skończenie wiele ogniw. Zatem każdy taki łańcuch, prowadzący do skończonej przeszłości, musi dojść do pierwszego naturalnego inteligentnego projektanta. Jednakże w myśl przesłanki pierwszej ten pierwszy naturalny umysł, będąc nieredukowalnie złożonym, sam musiał zostać stworzony przez inteligentnego projektanta i stąd też rozpatrywany argument prowadzi do wniosku, że musi istnieć nadprzyrodzony inteligentny projektant. ${ }^{18}$

\footnotetext{
${ }^{16}$ Por. Penrose'a podsumowanie świadectw na rzecz twierdzenia, że „Wielki Wybuch [...] miał miejsce około $1.4 \times 10^{10}$ lat temu" (R. Penrose, The Road to Reality: A Complete Guide to the Laws of the Universe, Knopf, New York 2005, s. 704).

${ }^{17}$ Zauważmy, iż rozpatrywane rozumowanie nie wymaga, by przyczyna zawsze poprzedzała własny skutek, lecz mówi jedynie, że dzieje się tak wtedy, gdy czynnikiem przyczynowym jest inteligentny projektant osadzony w naturze, który projektuje i tworzy nieredukowalnie złożony system również w świecie natury, skutkiem czego system ten istnieje i funkcjonuje jako nieredukowalnie złożony.
} 
Wydaje się, że Behe miał coś podobnego na myśli w następującym fragmencie, gdzie spostrzega, iż w obrębie struktury pojęciowej ID występuje związek między kwestią przyczynowości wstecznej oraz kwestią istnienia nadnaturalnego projektanta:

\begin{abstract}
Możliwe zatem, że biochemicy w przyszłości wyślą z powrotem na młodą Ziemię komórki, które będą zawierać informację dla obserwowanych współcześnie struktur nieredukowalnie złożonych. Zgodnie z tym scenariuszem ludzie mogą być swoimi własnymi kosmitami, własną zaawansowaną cywilizacją. Oczywiście, hipoteza podróżowania w czasie prowadzi do oczywistych paradoksów (czegoś w rodzaju wnuków zabijających swoich dziadków, zanim narodziło się ich potomstwo), ale przynajmniej niektórzy fizycy są gotowi ją zaakceptować. Większość ludzi, jak ja, uzna takie scenariusze za niezadowalające, ale są one dostępne dla tych, którzy chcą uniknąć niepożądanych skojarzeń teologicznych. ${ }^{19}$
\end{abstract}

Behe zgadza się z przesłanką siódmą argumentu przypominającego stylem rozumowanie św. Tomasza z Akwinu, gdyż, przynajmniej w tym przypadku, uznaje przyczynowość wsteczną za „całkowicie niezadowalającą”. Pojawia się nawet sugestia, że akceptuje on „skojarzenia teologiczne", wypływające z teorii mini-ID.

\title{
4. Czy teoria mini-ID niesie implikacje dotyczące istnienia istot nadprzyrodzonych?
}

Argument omówiony powyżej opierał się na czterech założeniach, które nie są częścią teorii mini-ID. Teoria mini-ID nie mówi, że

\footnotetext{
${ }^{18}$ Warto odnotować, iż rozpatrywany argument nie wymaga, by Wszechświat był przestrzennie skończony, ani by liczba inteligentnych projektantów w świecie przyrody była skończona.

${ }^{19}$ BeHe, Czarna skrzynka Darwina..., s. 216-217.
} 
Wszechświat jest skończony $\mathrm{w}$ czasie, ${ }^{20}$ nie obstaje przy tym, że w świecie przyrody przyczyna poprzedza własny skutek, nie mówi, że ludzki umysł jest nieredukowalnie złożony, i nie twierdzi, że naturalne umysły, które zaprojektowały i stworzyły nieredukowalnie złożone systemy, same są nieredukowalnie złożone. $Z$ teorii tej, rozumianej $\mathrm{w}$ wąskim sensie, wynika jedynie tyle, że jeśli te cztery założenia są poprawne, to istnienie nadprzyrodzonego inteligentnego projektanta jest koniecznością. Czy te cztery jeśli chronią teorię mini-ID przed implikacjami, dotyczącymi istnienia istot nadprzyrodzonych? Z wąskiej definicji tego typu implikacji wynika, że tak jest w istocie:

(N) Twierdzenie $P$ niesie implikacje, dotyczące istnienia istot nadprzyrodzonych, wtedy i tylko wtedy, gdy z $P$ wynika, że istota nadprzyrodzona istnieje lub że istot nadprzyrodzonych nie ma.

Pojawia się tutaj pytanie, czy jest możliwa jakaś szersza, wiarygodna interpretacja teorii, która niesie ,implikacje dotyczące istnienia istot nadprzyrodzonych". Rozważmy następującą definicję:

(B) Twierdzenie $P$ prowadzi do implikacji, dotyczącej istnienia istot nadprzyrodzonych, wtedy i tylko wtedy, gdy istnieją prawdziwe założenia pomocnicze $A$ takie, że nie z samego $A$, lecz z PiA wynika, iż istota nadprzyrodzona istnieje lub że istot nadprzyrodzonych nie ma.

W świetle tego szerokiego kryterium teoria mini-ID prowadzi do implikacji, dotyczących istnienia istot nadprzyrodzonych. Jednakże kryterium (B) jest problematyczne, gdyż wynika z niego, iż każde fał-

\footnotetext{
${ }^{20}$ Niektórzy teoretycy ID mówią o skończonym wieku Wszechświata. Na przykład Ross włącza tę tezę do swojego argumentu z subtelnego zestrojenia, który przemawia na rzecz istnienia Boga (H. Ross, „Big Bang Model Refined by Fire”, w: Dembski (ed.), Mere Creation..., s. 373 [363-384]).
} 
szywe twierdzenie $\mathrm{P}$ będzie miało takie implikacje. Bierze się to stąd, że jeśli $P$ jest fałszywe, to alternatywa ,nie- $P$ lub istoty nadprzyrodzone istnieją" jest prawdziwa, ale nie wynika z niej, że istoty nadprzyrodzone istnieją. Natomiast $\mathrm{z}$ koniunkcji tej alternatywy ze zdaniem $P$ wynika już, że istoty nadprzyrodzone istnieją. Błąd zawarty w (B) przypomina problemy pozytywistów logicznych, które wyszły na jaw, kiedy próbowali oni zdefiniować, co to znaczy, iż twierdzenie posiada konsekwencje obserwacyjne. Powtarzające się niepowodzenia kolejnych sformułowań weryfikacyjnej teorii znaczenia powinny służyć jako ostrzeżenie związane z niniejszym przedsięwzięciem. ${ }^{21}$

Skłaniam się ku twierdzeniu, iż pojęcia posiadania implikacji dotyczących istnienia istot nadprzyrodzonych, jak i pojęcia posiadania konsekwencji obserwacyjnych nie da się wyjaśnić jedynie za pomocą narzędzi logiki dedukcyjnej. Podejrzewam, że oba te pojęcia mają raczej charakter epistemiczny. Uwzględniając ideę testowalności obserwacyjnej, proponuję, co następuje:

(Ob) Twierdzenie $P$ ma konsekwencje obserwacyjne wtedy i tylko wtedy, gdy istnieją założenia pomocnicze $A$ oraz sąd obserwacyjny $O$ takie, że (i) z PiA wynika $O$, jednakże z samego $A$ nie wynika $O$, (ii) $A$ jest prawdziwe, (iii) mamy powody, by wierzyć w prawdziwość $A$ i (iv) uzasadnienie naszego przekonania o prawdziwości $A$ nie zależy od przekonania o prawdziwości (lub fałszywości) $P$, jak również nie zależy od przekonania o prawdziwości (lub fałszywości) $O$.

\footnotetext{
${ }^{21}$ C. Hempel, „Problems and Changes in the Empiricist Criterion of Meaning”, Revue Internationale de Philosophie 1950, vol. 11, s. 41-63. Zmienioną i rozszerzoną wersję artykułu przedrukowano jako „Empiricist Criteria of Cognitive Significance - Problems and Changes”, w: C. Hempel, Aspects of Scientific Explanation and Other Essays, Free Press, New York 1965.
} 
Dalsze rozważania na temat tego kryterium wymagałyby omówienia, czym jest sąd obserwacyjny, ${ }^{22}$ ale myślę, że w tym kontekście nie musi nas to interesować. Kryterium $(\mathrm{Ob})$ słusznie uznaje, iż prawa optyki mają obecnie konsekwencje obserwacyjne, dotyczące występowania zaćmień. Przewidywania te nie wynikają z samych praw, lecz kiedy uwzględnimy niezależnie uzyskaną wiedzę o Ziemi, Słońcu i Księżycu, powstała $\mathrm{w}$ ten sposób koniunkcja będzie posiadała takie implikacje.

Kryterium (Ob) jest indeksowane w zależności od czasu („teraz” reprezentuje jakikolwiek czas $t$ ) tak, iż w jednym czasie twierdzenie może nie mieć konsekwencji obserwacyjnych, chociaż posiada je w innym. Sytuacja ta obrazuje fakt, iż zupełnie sensownie można uznać, że dane twierdzenie może być w jednym czasie empirycznie testowalne, zaś w innym - nie. Jednakże kryterium $(\mathrm{Ob})$ nie wyklucza możliwości, że mogą istnieć inne, bardziej „modalne” wyjaśnienia testowalności. Ktoś mógłby na przykład chcieć zdefiniować jakieś ponadczasowe pojęcie, w którym twierdzenie $P$ ma konsekwencje obserwacyjne dokładnie wtedy, gdy istnieje prawdziwe twierdzenie pomocnicze $A$, które może być uzasadnione niezależnie od posiadanych przekonań o prawdziwości lub fałszywości $P$ oraz $O$, gdzie $O$ wynika z $P i A$, ale nie z samego $A$. To bardziej modalne pojęcie testowalności byłoby potrzebne, gdyby ktoś zechciał powiedzieć, że pewne twierdzenia nie tylko nie mogą zostać poddane testom obecnie, ale ze swej istoty pozostana nietestowalne już na zawsze. Jest to idea zasadniczej nietestowalności, którą chcieli wyodrębnić pozytywiści. Nie istnieje żaden szczególny problem ze zdefiniowaniem tego pojęcia (chociaż należy wyjaśnić pojęcie możliwości); trudność wiąże się raczej z zastosowaniem go. Aby móc powiedzieć, że twierdzenie jest nietestowalne z zasady, musimy dysponować wszechwiedzą na temat przyszłości badań naukowych; ktoś mógłby powiedzieć, że nigdy nie zostanie odkryta żadna pomocnicza zasada $A$, dzięki której $P$ miałoby konsekwencje

${ }^{22}$ E. Sober, „Testability”, Proceedings and Addresses of the American Philosophical Association 1999, vol. 73, s. 47-76; E. Sober, „Empiricism”, w: M. Curd and S. Psillos (eds.), The Routledge Companion to the Philosophy of Science, w druku. 
obserwacyjne. $Z$ tego też powodu wolę słabsze i mniej modalne pojęcie testowalności - pojęcie testowalności teraz. Oczywiście, jeśli twierdzenie jest testowalne teraz, jest testowalne także $w$ zasadzie. Jeśli jednak twierdzenie nie może zostać przetestowane teraz i ktoś nie potrafi sobie wyobrazić, by ten stan rzeczy kiedykolwiek się zmienił, moglibyśmy zapytać, o czym to świadczy? Czy w takim razie twierdzenie jest nietestowalne z zasady, czy może kogoś po prostu zawodzi wyobraźnia? Nie musimy obecnie zajmować się tym pytaniem.

Poniższa definicja tego, co to znaczy, że twierdzenie ma aktualnie implikacje, dotyczące istnienia istot nadprzyrodzonych, jest analogiczna do definicji konsekwencji obserwacyjnych zawartej w (Ob):

(E) Twierdzenie $P$ posiada obecnie implikacje, dotyczące istnienia istot nadprzyrodzonych, wtedy i tylko wtedy, gdy istnieją założenia pomocnicze $A$ takie, że (i) z PiA wynika, że istoty nadprzyrodzone istnieją lub nie istnieją, jednakże z samego $A$ nie wypływają takie implikacje, (ii) $A$ jest prawdziwe, (iii) mamy dobre powody, by wierzyć w prawdziwość $A$, (iv) uzasadnienie naszego przekonania o prawdziwości $A$ nie zależy od przekonania o prawdziwości (lub fałszywości) $P$, jak również jest niezależne od przekonania, że istoty nadprzyrodzone istnieją (lub nie istnieją).

Z tego epistemicznego kryterium wynika, że teoria mini-ID posiada obecnie implikacje, dotyczące istnienia istot nadprzyrodzonych, a to dlatego, iż mamy powody, by sądzić, że cztery założenia użyte we wcześniej zaprezentowanym argumencie oraz ich uzasadnienie nie zależą od przyjęcia teorii mini-ID (lub jej negacji), ani od naszych przekonań co do tego, czy istoty nadprzyrodzone istnieją.

Dlaczego mielibyśmy przyjąć epistemiczny opis $E$, mówiący o tym, co to znaczy, że twierdzenie posiada implikacje dotyczące istnienia istot nadprzyrodzonych? Dlaczego nie odrzucić tego opisu i nie przyjąć wyłącznie węższego kryterium $(\mathrm{N})$ ? Powodu dostarcza nam 
podobieństwo do problemu zdefiniowania pojęcia konsekwencji obserwacyjnych. Duhem ${ }^{23}$ miał rację twierdząc, iż teorie fizyczne, same przez się, nie mają konsekwencji obserwacyjnych. Jednak błędem byłoby uznanie, że teorie te nie posiadają takich konsekwencji. W tym samym sensie prawdą jest, że ludzie sami przez się nie mogą mieć dzieci, jednak błędem byłoby uznać, iż ludzie nigdy nie mają dzieci. Potrzebna jest koncepcja konsekwencji obserwacyjnych, uwzględniająca pogląd Duhema, ale wyjaśniająca również, jak za pomocą teorii można formułować przewidywania obserwacyjne. Kryterium (Ob) spełnia ten wymóg. To samo podejście prowadzi do propozycji zawartej $w(E)$.

Kryterium (E) definiuje pojęcie posiadania implikacji, dotyczących istnienia istot nadprzyrodzonych, jednak nie definiuje ogólniejszego pojęcia posiadania implikacji, dotyczących nadnaturalizmu. Aby zrozumieć różnicę, rozważmy tezę, w myśl której istnieje co najwyżej jedna istota nadprzyrodzona. Mimo iż z tej tezy nie wynika, jakoby istota nadprzyrodzona istniała, ani tym bardziej, że żadna taka istota nie istnieje, w pewnym intuicyjnym sensie niesie ona implikacje, dotyczące nadnaturalizmu. Nie wiem, w jaki sposób można by określić tę ogólniejszą kategorię, ale nie jest to konieczne dla naszych obecnych celów.

Czy zgodnie z kryterium (E) również darwinowska teoria ewolucji ma implikacje dotyczące istnienia istot nadprzyrodzonych? Sądzę, że odpowiedź brzmi: nie. Kiedy mówię o „teorii darwinowskiej”, mam na myśli dwa twierdzenia - że wszystkie organizmy żyjące dzisiaj (na Ziemi) pochodzą od wspólnego przodka ${ }^{24}$ i że dobór naturalny był

${ }^{23}$ P. Duhem, The Aim and Structure of Physical Theory, Princeton University Press, Princeton 1954 (1914).

${ }^{24}$ Darwin zazwyczaj wypowiadał się, że cofanie się w przeszłość doprowadzi do ,jednego lub kilku" pierwszych przodków (por. K. DARwIN, O powstawaniu gatunków drogą doboru naturalnego, czyli o utrzymaniu się doskonalszych ras w walce o byt, przeł. Szymon Dickstein i Józef Nusbaum, Ediciones Altaya Polska i DeAgostini Polska, Warszawa 2001, s. 560). Typowe sformułowania współczesnej teorii ewolucji, bazujące na świadectwach, którymi nie dysponował Darwin, idą zwykle dalej. 
ważną przyczyną podobieństw i różnic, jakie obserwujemy wśród współcześnie żyjących organizmów. ${ }^{25}$

Rozumiejąc teorię Darwina w ten sposób, rozważmy dwa następujące stwierdzenia: (i) albo teoria Darwina jest fałszywa, albo istota nadprzyrodzona istnieje; (ii) albo teoria Darwina jest fałszywa, albo nie istnieją żadne nadprzyrodzone istoty. Oczywiście teista, który uznaje Boga za istotę nadprzyrodzoną, wyrazi poparcie dla (i), natomiast naturalista zgodzi się z (ii). Zauważmy jednak, że ktoś, kto będąc agnostykiem nie przesądza o prawdziwości naturalizmu czy teorii Darwina, nie powinien zaakceptować żadnego $\mathrm{z}$ tych twierdzeń. W tym sensie teoria Darwina ma obecnie neutralny stosunek wobec kwestii istnienia istot nadprzyrodzonych. ${ }^{26}$ Widzimy tutaj istotną różnicę między teorią ID (minimalistyczną czy bardziej pojemną) a teorią ewolucji.

\section{Czy implikowanie nadnaturalizmu ma charakter religijny?}

Według kryterium poznawczego (E) teoria mini-ID sugeruje, że istnieje nadprzyrodzony inteligentny projektant, który jest twórcą jednego lub więcej umysłów występujących w przyrodzie. Czy należy postrzegać to twierdzenie egzystencjalne jako twierdzenie o charakterze religijnym? Oczywiście, nie głosi ono, że omawiany projektant posiada wszystkie cechy chrześcijańskiego Boga. Jednakże nie wystarcza to do udowodnienia, że teoria mini-ID nie jest teorią religijną; przecież oprócz chrześcijaństwa istnieją też inne religie. Być może

\footnotetext{
${ }^{25}$ Biologowie ewolucyjni, będący zwolennikami adaptacjonizmu, posuwają się dalej twierdząc, że dobór naturalny jest najważniejszą lub jedyna ważną przyczyną podobieństw i różnic obserwowanych wśród organizmów.

${ }^{26}$ Sytuacja tezy, że nasza aktualna wiedza nie dostarcza niezależnie potwierdzonego twierdzenia pomocniczego, pozwalającego uznać, iż teoria Darwina niesie implikacje, dotyczące istnienia nadprzyrodzonych projektantów, może ulec zmianie wraz z dalszym rozwojem wiedzy. Nie spodziewam się tego; jednak formułowanie przewidywań nie ma wpływu na rozwijany przeze mnie argument.
} 
gdyby nadprzyrodzona inteligencja, na jaką wskazuje teoria mini-ID, zastugiwała, by oddawać jej cześć, byłaby to oznaka, że teoria ta nie tylko implikuje nadnaturalizm, ale i ma konsekwencje religijne. Jeśli teoretycy ID chcą temu zaprzeczyć, muszą wytłumaczyć, dlaczego.

Sformułowałem przesłankę pierwszą tak, aby ograniczała się do tych obiektów $w$ naturze, które wykazują cechy nieredukowalnej złożoności. Obrońcy teorii mini-ID muszą wyjaśnić, dlaczego ich teoria powinna mieć takie ograniczenie. Być może zechcą argumentować, że nadprzyrodzony inteligentny projektant jest istotą wieczna i samowystarczalna i dlatego nie potrzebuje przyczyny zewnętrznej, by zacząć istnieć i trwać w istnieniu. Mogą też utrzymywać, że nadprzyrodzony projektant jest istotą prosta i dlatego nie będzie wykazywał żadnych złożonych cech. Nie mogą natomiast powiedzieć, że ich teoria jest teorią agnostyczną, jeśli chodzi o istnienie nadprzyrodzonych projektantów, gdyż, jak mieliśmy okazję właśnie zobaczyć, tak nie jest.

\section{Zakończenie}

Rozstrzygnąć o tym, czy teoria mini-ID niesie implikacje nadnaturalistyczne i religijne, nie jest tak łatwo, jak rozsądzić, czy słowo „Bóg” pojawia się w stwierdzeniu „każdy nieredukowalnie złożony system odnaleziony w przyrodzie został zaprojektowany i stworzony przez istotę inteligentną". Kiedy weźmiemy pod uwagę cztery założenia, których wiarygodność została ustalona niezależnie, teoria mini-ID będzie pociągała za sobą istnienie nadprzyrodzonego inteligentnego projektanta, który stworzył przynajmniej jeden z umysłów, znajdujących się w przyrodzie.

W artykule dowodziłem, że darwinowska teoria ewolucji milczy na temat tego, czy Bóg (uznany za istotę nadprzyrodzoną) istnieje. Czy jednak można stwierdzić to samo odnośnie innych współczesnych 
teorii naukowych? Według Johnsona ${ }^{27}$ na gruncie nauki ideologią panującą stał się naturalizm (pogląd, wedle którego istoty nadprzyrodzone nie istnieją). Uważa on, iż ten stan rzeczy jest wynikiem uprzedzeń, które należy przezwyciężyć, i nalega, by naukę jako całość (nie tylko biologię ewolucyjną) przekształcić $\mathrm{w}$ bardziej otwarte przedsięwzięcie, w którym również hipotezy dotyczące sfery nadprzyrodzonej będą uczciwie rozpatrywane. Wybitny biolog ewolucyjny Richard Lewontin ${ }^{28}$ zgadza się z tym, że współcześni naukowcy są zdeklarowanymi naturalistami, ale nie uważa wcale, by stanowiło to jakiś problem. Twierdzi, że badania naukowe wymagają apriorycznej wierności materializmowi, a zatem i naturalizmowi.

Robert Pennock, ${ }^{29} \mathrm{w}$ odpowiedzi Johnsonowi, odróżnia naturalizm metodologiczny od naturalizmu metafizycznego i twierdzi, że nauka podlega tylko temu pierwszemu. Według Pennocka nauka musi ograniczać się do wyjaśnień naturalistycznych nie dlatego, iż zakłada nieistnienie istot nadprzyrodzonych, ale dlatego, że twierdzenia na temat istnienia takich istot nie są testowalne. Nie miejsce tu na sprawdzanie tez metodologicznych Pennocka, jednak warto zauważyć, że pewne twierdzenia dotyczące istot nadprzyrodzonych (np. twierdzenie, wedle którego wszechmogąca istota nadprzyrodzona chciała ponad wszystko, by każdy element przyrody miał kolor fioletowy) są testowalne. ${ }^{30}$ Chciałbym tutaj podkreślić inną sprawę - jak zauważył Pennock, ${ }^{31}$ darwinowska teoria ewolucji milczy na temat istnienia nadprzyrodzonego inteligentnego projektanta. Nie możemy powiedzieć tego samego o teorii mini-ID. Pod względem treści teorii to nie teoria ewolucji,

\footnotetext{
${ }^{27}$ Johnson, Sąd nad Darwinem..., s. 20-22, 145-146.

${ }^{28}$ R. Lewontin, „Billions and Billions of Demons”, New York Review of Books, 9 January 1997, s. 28-32.

${ }^{29}$ R. Pennock, Tower of Babel: The Evidence against the New Creationism, MIT Press, Cambridge 1999.

${ }^{30}$ E. Sober, Philosophy of Biology, Westview Press, Boulder, Colorado 1993.

${ }^{31}$ Pennock, Tower of Babel....
} 
lecz teoria ID niesie implikacje, dotyczące istnienia nadprzyrodzonych projektantów. ${ }^{32}$

Elliott Sober

${ }^{32}$ Przydatnymi uwagami odnośnie do niniejszego artykułu, za co jestem im niezmiernie wdzięczny, podzieli się ze mną Glenn Branch, David Christensen, Juan Comesaña, Matthew Davidson, Branden Fitelson, Daniel Hausman, Christopher Hitchcock, David Malament, William Mann, Gregory Mougin, Ronald Numbers, Robert Pennock, Carolina Sartorio, Larry Shapiro, jak również redaktor naczelny oraz anonimowi czytelnicy tego czasopisma [Faith and Philosophy]. 